\title{
Necessity Nonprofit Entrepreneurship: A Study of Extrinsically Motivated Nascent Nonprofit Entrepreneurs
}

\author{
${ }^{1}$ Indiana University-Purdue University Indianapolis School of Public and Environmental Affairs, Indianapolis, IN 46202-5199, \\ USA, E-mail: fanders@iu.edu
}

\begin{abstract}
:
Individuals creating new nonprofit organizations are often viewed as being driven by intrinsic and altruistic motives pulling them into becoming a nonprofit entrepreneur. However, individuals can also be pushed towards self-employment in the nonprofit sector because of negative external forces, a phenomenon labeled necessity nonprofit entrepreneurship. This article explores necessity nonprofit entrepreneurs to illustrate how they differ from those not explicitly driven by necessity in starting up a new nonprofit, and what policy implications and questions necessity nonprofit entrepreneurship raises for nonprofit stakeholders.
\end{abstract}

Keywords: nonprofit entrepreneurship, necessity entrepreneurs

DOI: $10.1515 / \mathrm{npf}-2017-0024$

In his seminal paper, Gartner $(1988,11)$ states that entrepreneurship is the creation of organizations and "[w]hat differentiates entrepreneurs from non-entrepreneurs is that entrepreneurs create organizations, while nonentrepreneurs do not." This minimalistic, yet powerful, viewpoint has played a central role in shaping business entrepreneurship scholarship and practice (Hjorth and Johannisson 2008). The notion that the earliest phase(s) of nonprofit organizational life is associated with specific attributes, activities, and challenges has long been recognized by nonprofit life-cycle scholars (e. g. Hasenfeld and Schmid 1989; Bess 1998; Simon 2001; Stevens 2001). Still, the process of new nonprofit venture creation remains relatively understudied, especially when compared to the massive research focusing on new business enterprise creation (Van Slyke and Lecy 2012). As commented by Carman and Nesbit $(2013,604)$, " [...] empirically, we will still know comparably less about why these new nonprofit organizations continue to be founded." More recently, however, a growing number of publications have started paying close attention to the formation process of new nonprofit organizations (i. e., nonprofit entrepreneurship), and the individual(s) that create them (i. e., nonprofit entrepreneurs) (Van Slyke and Lecy 2012; Carman and Nesbit 2013; Andersson 2016; Dollhopf and Scheitle 2016). The renewed interest in nonprofit entrepreneurship and nonprofit entrepreneurs is not surprising given the rising popularity and profile of the neighboring (and often overlapping) social entrepreneurship and social enterprise fields, and the asserted positive socio-economic impact generated by social entrepreneurial activity (Harding 2004; Santos 2012). Funders and policy makers are also paying more attention to nonprofit/social entrepreneurs, recognizing social sector entrepreneurship as a pathway to advance a wide range of vital functions, including social change, job creation, income generation, and social innovation, to name a few (Haugh 2005; Van Slyke and Lecy 2012).

As observed by Stevens $(2001,27)$, the first life stage of a new nonprofit venture is often bewildering and unsystematic. Still, the nonprofit entrepreneur is "[...] very clear, and often messianic, about the why of their venture." According to Carman and Nesbit (2013), nonprofit entrepreneurs are typically depicted as passionate, inspirational, and ideologically motived, with the potential to offer alternate and/or novel solutions to pressing social problems. Social entrepreneurship researchers have also examined and reinforced the significance of intrinsic, and largely altruistic, motivations propelling social sector entrepreneurs to create new social ventures (Germak and Robinson 2014). This article seeks to move beyond the notion of the nonprofit entrepreneur as inherently altruistic and intrinsically driven, to take into consideration more mundane and extrinsic motivations. The impetus for expanding the scope and current understanding of the nonprofit entrepreneur is a noteworthy discovery reported by Carman and Nesbit $(2013,615)$, recognizing some nonprofit entrepreneurs are best described as "reluctant entrepreneurs" as circumstances push them into creating new nonprofits. This depiction of the nonprofit entrepreneur is far removed from the sunny and fervent image often found in the social entrepreneurship literature (see for example Bornstein 2004). The phenomenon described by Carman and Nesbit has elsewhere been referred to as necessity entrepreneurship, that is, having to become an entrepreneur 
because you have no better or available options (Reynolds et al. 2003). Hence, this article argues that necessity nonprofit entrepreneurs represent a particular form or type of nonprofit entrepreneur. The concept and significance of necessity entrepreneurs and entrepreneurship have for the most part been linked to new small business creation, often in a developing world context (Brewer 2014), yet have received scarce attention in the nonprofit literature. This author knows of no previous empirical studies examining necessity nonprofit entrepreneurs in a U.S. context.

Still, if nonprofit entrepreneurship can be segmented, as inferred by Carman and Nesbit, then this heterogeneity may have implications for the design, funding, and success of nonprofit entrepreneurship policies. For example, funders and policymakers would not only be interested in knowing more about what differentiates various types of nonprofit entrepreneurship, but also the implications of targeting and/or supporting specific types of nonprofit entrepreneurship. The purpose of this article is therefore (i) to examine closer the notion of necessity entrepreneurs and explore how necessity nonprofit entrepreneurs differ from nonprofit entrepreneurs not driven by necessity, and (ii) discuss policy considerations of necessity entrepreneurship in a nonprofit sector context. Given the lack of research on necessity entrepreneurship in the nonprofit sector, this article will largely draw from necessity entrepreneurship research conducted by business scholars, but also seek to add insights from nonprofit organizational- and social entrepreneurship research. Thus, it is important to recognize that this is exploratory research and that the article is first and foremost a vantage point for additional research and discussion on necessity entrepreneurship in a nonprofit sector context.

\section{What Motivates Entrepreneurs to Start New Ventures?}

The role of motivation in explaining new business venture formation has a long history (Segal, Borgia, and Schoenfeld 2005). New ventures do not emerge from nothing, they are created because entrepreneurs are interested and willing to engage in new venture creation (Shane, Locke, and Collins 2003). Business entrepreneurship research recognizes that entrepreneurs start and operate new firms for many different reasons, both extrinsic and intrinsic in nature. Scholars have sought to explore what motivations are more important to entrepreneurs and how they differ from individuals that do not undertake business venturing activity (Shane, Locke, and Collins 2003).

Nonprofit scholars have indeed recognized the role of individual motivation in new nonprofit venture creation (Young 1983; Handy, Kassam, and Renade 2002), but mostly focused on broader demand and supply dynamics to explicate why there is a nonprofit sector and why new nonprofit organizations are created (Frumkin 2002; Child, Witesman, and Braudt 2015). However, more recently, researchers have started to investigate the motivation of individual social entrepreneurs finding a variety of motives for starting new social ventures (e. g., Vogl 2015).

There is a common belief that entrepreneur motivations are not consistent across all types of venturing activity. For example, Handy, Kassam, and Renade $(2002,140)$ note there are many similarities among business- and nonprofit entrepreneurs with the main difference being their primary motivation: business entrepreneurs are motivated by making profits whereas nonprofit entrepreneurs are motivated by promoting a social cause. Likewise, Sastre-Castillo, Peris-Ortiz, and Valle $(2015,349)$ argue social entrepreneurs are always driven by the intention to solve social problems. Hence, it is often assumed that nonprofit entrepreneurs are principally guided by intrinsic, and often altruistic, motivations (Carman and Nesbit 2013). However, as discussed in the next section, it is perhaps time to start challenging this assumption.

\section{What Is a Necessity Nonprofit Entrepreneur?}

The basis for comprehending what a necessity nonprofit entrepreneur is can be traced back to Young's (1983) seminal contribution on what stimulates individuals to start new nonprofit activity. He classified nonprofit entrepreneurs into various types, and two types are of particular interest for this study: the searcher and the income seeker. Young depicts the searcher as (64) "restless and frustrated" and in pursuit to escape his/her present, and often unsatisfying, situation in pursuit of something different. Income seekers are individuals primarily driven by (66) "the motive of material self-aggrandizement" in the form of future capital gain and income. The income seeker is thus highly reminiscent to the business entrepreneur who starts a new venture because she/he has discovered an opportunity that allows them to extract entrepreneurial profits (Shane and Venkataraman 2000). 
What makes Young's observation significant is that it demonstrates how extrinsic motivations, including self-employment and income, indeed can play a role in explaining nonprofit entrepreneurship. Moreover, it also recognizes not all nonprofit entrepreneurs are the same, and that the differences in the underlying driving forces of nonprofit entrepreneurs are likely to be accompanied by differences in output and performance that are central to sort out and understand.

Three decades later, Carman and Nesbit (2013) examination of nonprofit entrepreneurs brings a complementary dimension to Young's work by showing how, within the group of income seekers, there is an additional important distinction to be made. Carman and Nesbit note the desire for self-employment can indeed be a potent motivation when examining why new nonprofits emerge. In their study, they found most of the nonprofit entrepreneurs seeking a steady income from self-employment created new organizations because it offered them an opportunity (613) "[...] to make a living doing what they love." However, Carman and Nesbit also found nonprofit entrepreneurs being pushed into creating a new nonprofit to escape detrimental situations such as job loss or inability to get a first job. This differentiation is vital because it acknowledges that nonprofit entrepreneurship, in some cases, is a self-employment choice out of necessity rather than a positive choice to take advantage of an opportunity. Hence, what defines the necessity nonprofit entrepreneur is that he/she is pushed, feeling compelled by circumstances, to start a new nonprofit.

Business entrepreneurs driven by necessity represent a "sizeable group in all countries" (Poschke 2013, 662). Still, the notion of a social- or nonprofit necessity entrepreneur remains a bewildering concept. For example, Germak and Robinson $(2014,9)$ imply becoming a social entrepreneur " [...] may necessitate a more complex level of motivational bases; it would not be enough, for example, if the social entrepreneur were motivated by satisfying himself or herself alone without some greater self-actualizing purposes." Also, rather than considering becoming a social entrepreneur a result of necessity, the prevailing narrative predominantly depicts the social entrepreneur as a person helping others in need to escape from unemployment or impoverishment (Zahra et al. 2009).

\section{Are Necessity Nonprofit Entrepreneurs Different?}

A basic argument for paying attention to necessity nonprofit entrepreneurs is that by distinguishing this group from other types of nonprofit entrepreneurs we can begin to make headway in understanding how various forms of entrepreneurship affect the nonprofit sector. For example, if nonprofit entrepreneurship comes in different guises, policy makers and other stakeholders could benefit from knowing more about the attributes of the various forms of nonprofit entrepreneurship to inform and guide strategic decision-making process and the allocation of resources.

Principal to the above argument is the idea that necessity and non-necessity nonprofit entrepreneurship are different. In addition to the motivational difference, this section highlights three further reasons to suppose necessity nonprofit entrepreneurship is different from its non-necessity peer. These differences, in turn, serves as the basis for a number of propositions regarding necessity nonprofit entrepreneurship. It is important to note that the propositions are derived from the business entrepreneurship literature given the dearth of nonprofit research devoted to necessity entrepreneurship. Also, as concluded by Handy, Kassam, and Renade (2002, 150), "[...] typologies developed for the for-profit sector are also relevant to the nonprofit sector. This finding, along with certain similarities of entrepreneurs in the two sectors, underscores the likelihood that entrepreneurs share certain characteristics in general [...]."

An initial proposition is that nonprofit venture activities created by necessity nonprofit entrepreneurs are more likely to be short-term and short-lived entities. If self-employment in the nonprofit sector is not the preferred preference of the nonprofit entrepreneur, it is feasible to assume the new venture being created is not going to be looked upon as a long-term endeavor. In other words, the new venture functions as a stopgap activity that will be discontinued as soon as the necessity nonprofit entrepreneur finds a better opportunity (Gibson 2014). Furthermore, as noted by Block et al. (2015), necessity entrepreneurs typically have less time, fewer resources available, and less know-how in terms of starting new venture activities compared to other types of entrepreneurs. Ultimately, as Brewer $(2014,19)$ concludes, necessity entrepreneurs frequently "[...] lack the awareness of how to do what needs to be done to succeed." Thus, in addition to the above bridging feature, necessity nonprofit entrepreneurship efforts are also postulated to be more prone to start-up failure. Starting up a new nonprofit is no easy endeavor. Andersson and Ford (2017) looked at new nonprofit voucher schools in Milwaukee and found seven of ten start-up efforts resulting in failure. Because necessity nonprofit entrepreneurs are pushed into starting new nonprofit ventures, they will be even less prepared (Brewer 2014), and therefore disadvantaged, to operate such a venture compared to those entrepreneurs who carefully plan their new nonprofit initiative and develops a more robust capacity for the start-up effort (Andersson 2016). 
Nonprofit ventures created by necessity nonprofit entrepreneurs are likely to be small, but also postulated to remain small. Private sector data has shown businesses created by necessity entrepreneurs are on average smaller and have lower growth expectations (Poschke 2013). Though most nonprofits in the US tend to be small (McKeever 2015), it seems reasonable to make similar predictions regarding scale/growth when it comes to necessity nonprofit entrepreneurship. According to Gibson $(2014,26)$ necessity entrepreneurs tend to focus on the short-term and the urgent, which "[...] causes them to miss out on business strategies such as analyzing past results, planning for future growth, or seeking out new customers." Poschke (2013) adds operating a venture created out of necessity significantly increases the probability of not having employees. He further notes necessity entrepreneurs are less likely to expect having any employees in the future when compared to non-necessity entrepreneurs. Indeed, if necessity entrepreneurs operate and perceive their ventures using a short-term perspective, making upfront investments aimed at future growth are not going to be a main priority. Finally, by operating on a small scale (and actively seeking to stay small) the necessity nonprofit entrepreneur can maintain greater control of the new venture. Gibson (2014) notes necessity entrepreneurs frequently pivot and make changes to their ventures, and to allow for such pivoting to take place, it is essential for the entrepreneur to have discretion and flexibility.

The final propositions are that necessity nonprofit entrepreneurship will be less impactful and less innovative than other forms of nonprofit entrepreneurship. Given the postulated smallness of necessity nonprofit ventures, it is likely their impact will also be rather limited. In an interesting article, Acs $(2006,102)$ examined the relation between entrepreneurship and economic development, and makes the argument that if the goal of the entrepreneur is merely self-employment, the type of entrepreneurship it generates "will not lead to economic development because there is no mechanism to link the activity to development." Acs even suggests that the ratio of opportunity-to-necessity entrepreneurship can serve as an indicator of just how impactful entrepreneurial activity will be in a specific context. Gibson $(2014,27)$ further underscores how necessity entrepreneurs are unlikely to utilize the tools and techniques necessary for creating a good foundation for generating major impact:

[...] they often do not make time to keep records or even see the point in doing so. They are comfortable keeping their knowledge of their business in their head. Consequently, they do not have the data they need to make good business decisions.

This is not to say necessity nonprofit entrepreneurs do not work very hard, or that necessity ventures do not produce any impact. But if you lack many of the financial and strategic features necessary for making wellinformed operational decisions, it will sooner or later undermine your ability to steadily generate impact.

Necessity entrepreneurs are also less likely to be innovators. New nonprofits have been depicted as key carriers of new innovative ideas (Chambré and Fatt 2002), and some research suggests new nonprofit start-ups to indeed be very innovative (Van Slyke and Lecy 2012).

However, according to Block et al. (2015), necessity entrepreneurs are often individuals with sparse human capital (which is why they often have a hard time finding employment), and therefore unlikely to possess the type of know-how needed for creating innovative products and/or services. Instead, they will focus on and be limited to produce more standard (or modest) outputs, and seek to compete with a low-cost strategy. Pursuing an innovative strategy also means more risks given the liability of newness associated with novel and untested products and/or services. Hence, if the main goal is to secure an income it is safer to pursue something true and tested rather than jumping into the unknown. This assertion is supported by Gibson $(2014,26)$ who posits necessity entrepreneurs [...] tend to copy each other rather than differentiate their business."

Clearly the above propositions are tentative as this author knows of no empirical research comparing necessity and non-necessity nonprofit entrepreneurs. Therefore, with the goal of beginning to examine some of the propositions, an exploratory study was conducted using data from two surveys of a small sample of nonprofit entrepreneurs in Kansas City, MO.

\section{Necessity Nonprofit Entrepreneurs: an Empirical Snapshot}

The data for the first survey comes from individuals partaking in one of four "Planning a New Nonprofit"sessions offered by the Midwest Center for Nonprofit Leadership (MCNL) in Kansas City during the first half of 2015. MCNL is a service and outreach unit of the Department of Public Affairs in the Henry W. Bloch School of Management at the University of Missouri-Kansas City that offers a variety of support and programs to the Kansas City nonprofit sector. As many individuals connected with MCNL with questions regarding how to start and support new nonprofit ventures, the center developed the Planning a New Nonprofit-workshop in 2004 targeting any individual expressing an interest in starting a nonprofit organization. Hence, this service is explicitly directed toward nascent nonprofit entrepreneurs, that is, those engaged in activities that are intended 
to culminate in a viable organization. The workshop is free of charge; however, all participants must register before attending. MCNL promotes the workshop via its website, referrals, and newsletters. On average, six to seven sessions are offered annually, and each session attracts between fifteen to thirty nascent nonprofit entrepreneurs. Since 2011, the center has collected a variety of data from participants in an effort to evaluate and improve the program. MCNL's purpose with this specific survey was to capture information regarding early (pre-organization) start-up reasoning, intentions, and strategic considerations. The survey was distributed to participants in four "Planning a New Nonprofit"-sessions from January to July 2015. The facilitators of the program distributed a questionnaire before the program started and explained the purpose of the survey. Sixtynine nascent nonprofit entrepreneurs completed the survey.

At this point it is vital to note this study has obvious limitations. First, as stated earlier, this is an exploratory study aiming for illumination rather than theory testing. Second, the measures used were designed by MCNL with a focus on simplicity and brevity rather than scientific rigor. For example, many of the measures are based on only one item designed with a practical mindset rather than including robust and empirically validated empirical measures. The survey is meant to capture views from the workshop participants meaning the perspectives from other stakeholders related to the new venture were not considered. Hence, there are obvious self-report and overconfidence bias risks.

One of the questions included by MCNL asked each participant to indicate what primarily motivated them to initiate the process of creating a new nonprofit by selecting one of the following options: (i) I am creating this organization to respond to an unmet need in my community/society $(n=22)$, (ii) I am creating this organization as a vehicle to express my values and beliefs $(n=14)$, (iii) I am creating this organization because I have a new service/program/product idea I want to introduce and try out $(\mathrm{n}=4$, (iv) I am creating this organization because I want more autonomy (i. e., greater ability to make my own decisions) and be my own boss $(\mathrm{n}=13)$, (v) I am creating this organization because I have no better choices for work ( $\mathrm{n}=11)$, and (vi) other (if checked the respondent was asked to enter an explanation). (n. =5). A textbox for any comments/clarifications was also available. The results are much in line with what current nonprofit scholarship posits, proposed, nonprofit creation is driven by both instrumental and expressive motives (Frumkin 2002). Respondents answering either (i) or (ii) also frequently commented they were motivated to "help others" and/or being affected/close to a particular social problem they wanted solve. However, it is also clear more extrinsic motivations is a driver of new nonprofits. Those indicated wanting more autonomy also commented on a personal calling or need for personal fulfillment, supporting some of the findings by Carman and Nesbit (2013) and Germak and Robinson (2014).

Eleven of the sixty-nine respondents marked "I am creating this organization because I have no better choices for work" as the main motivation. Two answers in the Other-option also depicted noticeable push factors; one respondent indicating she felt "locked out" from the job market as a woman and saw no other solution than creating her own organization. The second respondent indicated it was "impossible" to get entry to the job market for young persons, so becoming an entrepreneur was the only remaining option to secure employment. These thirteen respondents ( $18.8 \%$ of the total sample) were considered necessity nonprofit entrepreneurs. In the subsequent analysis, the answers from the group deemed necessity nonprofit entrepreneurs $(\mathrm{n}=13)$ are compared and contrasted with the answers from the non-necessity group of nonprofit entrepreneurs $(n=56)$.

Perhaps not surprisingly, nine respondents in the necessity nonprofit entrepreneurs group indicated they were currently unemployed. Four respondents in the necessity nonprofit entrepreneurs group selected not to answer this question. The necessity group did not differ markedly from the rest of a sample in terms of gender distribution and age. However, only one respondent in the necessity nonprofit entrepreneur group indicated having started a new organization before compared to seventeen among the other respondents. Furthermore, all but one, or $92 \%$, in the necessity nonprofit entrepreneur group intended to start their new nonprofit alone compared to only $38 \%$ among the other respondents.

To begin comprehending whether necessity nonprofit entrepreneurs differ from their non-necessity peers, the MCNL survey included three start-up intentions/expectations areas: commitment, scale, and innovation. Commitment reflects to what extent the nonprofit entrepreneur perceives his/her emerging organization as an abiding long-term initiative or more of a short-term temporary project. As discussed earlier, one could hypothesize that necessity nonprofit entrepreneurs are more likely to utilize a start-up as a temporary platform from which they can search for new / different opportunities, and therefore not be as committed to the new nonprofit. The nascent entrepreneurs were asked to respond to the following statement using a five-graded Likert-scale ranging from strongly disagree to strongly agree: "I intend for this new organization to be a long-term project I will work on for many years to come."

It was also previously noted that necessity business entrepreneurs tend to operate smaller ventures and may have low growth expectations. To examine the extent to which nascent nonprofit entrepreneurs intend to scale their organization and operations, the participants in the study were asked to respond to the following two statements: "I intend to keep my new nonprofit small, primarily rely on volunteer labor and/or a small 
number of paid staff" [Scale 1], and "In the next five years I intend to grow and scale the social impact of my organization significantly." [Scale 2].

Lastly, the nascent nonprofit entrepreneurs were asked to respond to the following statement: "I intend to use my new nonprofit to introduce a completely new approach, method, service and/or product to serve the community and nonprofit sector." This item seeks to capture the innovative posture of the emerging organization. If the main purpose of necessity nonprofit entrepreneurs is to secure employment, it seems plausible to think they will engage in well-recognized activities rather than undertake activities that are untested and therefore lacks legitimacy in the eyes of external stakeholders.

Table 1 provides basic descriptive statistics for the commitment, scales, and innovation items.

Table 1: Descriptive statistics start-up objectives and expectations.

\begin{tabular}{|c|c|c|c|c|}
\hline & \multicolumn{2}{|c|}{$\begin{array}{l}\text { Necessity Entrepreneurs } \\
(n=13)\end{array}$} & \multicolumn{2}{|c|}{$\begin{array}{l}\text { Non-Necessity Entrepreneurs } \\
(n=56)\end{array}$} \\
\hline & $\underline{\text { Mean }}$ & s.d. & Mean & s.d. \\
\hline Commitment & 3.92 & 0.759 & 4.16 & 0.757 \\
\hline Scale 1 & 3.27 & 1.198 & 2.54 & 1.136 \\
\hline Scale 2 & 2.46 & 0.877 & 3.55 & 1.158 \\
\hline Innovation & 2.23 & 1.012 & 3.09 & 1.311 \\
\hline
\end{tabular}

The results in Table 1 offer little support for the presumption that the nascent necessity entrepreneurs view their emerging organizations as a limited short-termed activity. A Mann-Whitney $U$ test $(U=298, p=0.274)$ further reinforces that the difference between the two groups are not significant.

However, the descriptives for the scale and innovation items do indicate necessity nonprofit entrepreneurs appear more inclined to keep their emerging organizations small and intend for them to stay that way (Scale 1; $\mathrm{U}=243, \mathrm{p}=0.053$; Scale 2; $\mathrm{U}=171, \mathrm{p}=0.002$ ), and depict how the nascent nonprofit entrepreneurs stand out as less likely to introduce novel goods and services $(U=219, p=0.023)$. Taken together, being cognizant of the limited sample size, the nascent survey displays noticeable differences in start-up intentions/expectations between necessity nonprofit entrepreneurs and those not pushed into nonprofit entrepreneurship. It is also worth noticing how the group of necessity nonprofit entrepreneurs are more likely to be novice entrepreneurs planning to start a new organization by themselves rather than part of a start-up team.

\subsection{Follow-Up Survey}

Examining nonprofit entrepreneurs at the nascent stage is important because pre-organization intentions and strategic decisions at this stage end up shaping the trajectory of the new organization (Block et al. 2015). Yet, to gain deeper insight into the differences between necessity and non-necessity nonprofit entrepreneurs, it will be important to move beyond intentions and expectations to also examine the organization they create. Consequently, with the support of MCNL, a follow-up email survey went out February 2017 to sixty-seven of the respondents of the nascent stage survey (two of the contact email address lacked complete domain names). Fifty-four responded back, including all thirteen necessity nonprofit entrepreneurs from the initial survey.

The first question in the follow-up survey asked about start-up status (i. e., whether the respondent had formed and was currently operating a nonprofit, or if the start-up had been discontinued?) Four respondents (none in the necessity group) indicated they were still in the process of getting ready to launch their new venture. More than half $(51.9 \%)$ revealed they were no longer attempting to start a new nonprofit, including ten from the original necessity nonprofit entrepreneurship group. The respondents in the discontinued group were also asked to explain why they halted the founding process (this was an open-ended question). The most frequently mentioned reasons included difficulty mobilizing the needed/desired amount of start-up funding, organizational issues (e. g., not being able to recruit board members, and time-related problems). Some indicated losing interest, red tape, and difficulty retrieving information/key stakeholders as contributing factors. Securing start-up funding was the most frequently highlighted reason among the necessity group respondents. Given ten (or $76.9 \%$ ) in the necessity group selected to discontinue the start-up process compared to $43.9 \%$ in the non-necessity group, there appears to be some support for the proposition that necessity driven nonprofit entrepreneurship is more prone to start-up failure. Yet, the failure notion is multifaceted, (add comma) and more research and nuance are certainly needed to explicate the nonprofit start-up failure process. For example, an intriguing finding involved three of the necessity nascent nonprofit entrepreneurs highlighting employment elsewhere as one, albeit not the only, reason for discontinuation. One respondent even said he had founded a new nonprofit in 2015 but stopped operations in 2016 when hired by another nonprofit organization. This ob- 
servation not only problematizes the notion of start-up failure, but gives a nudge to the idea that necessity nonprofit entrepreneurs are more likely to utilize new nonprofits as temporary solutions and not long-term endeavors.

Turning to the twenty-two nonprofit entrepreneurs currently operating a nonprofit (three being necessity entrepreneurs), each respondent was first asked to provide some basic characteristics of their new organization, including number of full-time employees, board size, and budget size.

Though there are only three respondents in the necessity group, the descriptive breakdown presented in Table 2 still yields some noteworthy observations. In particular, the organizations created by the necessity nonprofit entrepreneurs are small-scale operations. They only employ the founder and have small boards (note that the minimum board size in Missouri is three, and in Kansas one). Furthermore, the budgets for the organizations created by necessity nonprofit entrepreneurs tend to be smaller compared to most of the budgets for organizations created by non-necessity nonprofit entrepreneurs. Even the three organizations in the nonnecessity group with no paid employees reported having larger budgets than the nonprofits in the necessity group. Taken together, nonprofits founded out of necessity appear to be lean and with limited capacity for significant impact. Not only do they operate with limited manpower but also with limited financial resources to put toward programs and services. The resources available for programs and services will further depend on how much money will flow to the necessity nonprofit entrepreneur as compensation.

Table 2: Descriptive statistics organizational characteristics.

\begin{tabular}{|c|c|c|c|c|}
\hline & \multicolumn{2}{|c|}{$\begin{array}{l}\text { Necessity Entrepreneurs } \\
(\mathrm{n}=3)\end{array}$} & \multicolumn{2}{|c|}{$\begin{array}{l}\text { Non-Necessity Entrepreneurs } \\
(n=19)\end{array}$} \\
\hline & Mean & s.d. & Mean & s.d. \\
\hline No. of Paid Employees & 1.00 & 0.000 & 3.92 & 0.759 \\
\hline Board Size & 2.67 & 0.577 & 5.37 & 1.342 \\
\hline Budget Size & $10,500.00$ & $1,322.87$ & $25,815.79$ & $14,330.63$ \\
\hline Budget Size (median) & 9,500 & & 19,000 & \\
\hline
\end{tabular}

At this point we can of course only speculate as to why nonprofits created by necessity nonprofit entrepreneurs have such a small footprint. One possible reason is the founder wanting to maximize control, which is easier when operating a smaller and leaner organization. Another reason could be lean organizations are less complicated to discontinue should new/alternative opportunities emerge. A third option is that necessity nonprofit entrepreneurs lack the know-how for how to build and operate a larger organization. As Gibson (2014, 27) puts it, "[...] providing more capital to someone who cannot or will not use it effectively often simply allows them [necessity entrepreneurs] to fail at a higher rate [...]."

The follow-up survey also revisited the question on commitment and one question about scale from the initial survey, and added one revised and two new questions on innovation: my new nonprofit has introduced a completely new approach, method, service and/or product to serve the community and nonprofit sector [revised Innovation1], my new nonprofit has introduced an approach, method, service and/or product that is a substantial improvement compared to what other nonprofits have offered before [Innovation 2], and my new nonprofit focus on beneficiaries that other nonprofits have totally neglected [Innovation 3]. The same fivegraded Likert-scale from the nascent survey was utilized. Table 3 displays basic descriptives for all questions.

Table 3: Descriptive statistics commitment, scale \& innovation variables.

\begin{tabular}{|c|c|c|c|c|c|c|}
\hline & \multicolumn{3}{|c|}{$\begin{array}{l}\text { Necessity Entrepreneurs } \\
(n=3)\end{array}$} & \multicolumn{3}{|c|}{$\begin{array}{l}\text { Non-Necessity Entrepreneurs } \\
(n=19)\end{array}$} \\
\hline & $\frac{\frac{\text { Nascent }}{\text { Survey }}}{\frac{\text { Mean }}{}}$ & Mean & s.d. & $\frac{\text { Nascent }}{\frac{\text { Survey }}{\text { Mean }}}$ & Mean & $\underline{s . d .}$ \\
\hline Commitment & 3.33 & 3.00 & 0.000 & 4.05 & 4.58 & 0.607 \\
\hline Scale 2 & 2.33 & 2.33 & 0.577 & 3.79 & 3.89 & 0.937 \\
\hline Innovation 1 & 1.67 & 2.00 & 0.000 & 3.47 & 2.84 & 0.958 \\
\hline Innovation 2 & $\mathrm{x}$ & 1.67 & 0.577 & $\mathrm{x}$ & 3.32 & 0.885 \\
\hline Innovation 3 & $x$ & 1.33 & 0.000 & $x$ & 2.37 & 0.607 \\
\hline
\end{tabular}

The long-term commitment among the non-necessity nonprofit entrepreneurs has increased from the first survey, resulting in a more pronounced difference between the two groups. Hence, the proposition necessity 
nonprofit entrepreneurs are less likely to consider their new ventures long-term endeavors appears to have some support when looking at post-nascent stage nonprofit entrepreneurs. The difference in the view on scale remains more or less unchanged, with necessity nonprofit entrepreneurs displaying less appetite for growth. The findings reported in Table 2 also suggest necessity nonprofit entrepreneurs prefer to operate small and lean organizations. Table 3 also reinforces the idea necessity nonprofit entrepreneurs are unlikely to launch new innovative ventures. However, the entrepreneurs in the non-necessity group were not particularly innovative either. Clearly the intent to innovate, displayed by the non-necessity group during the nascent stage, was not translated into innovative programs or services. Ultimately, when looking at the three innovations items together, most new nonprofits appear to be replicators rather than innovators.

\section{Policy Considerations}

Obviously, the empirical material presented in this article has many limitations. The data covers self-selected nonprofit entrepreneurs in one geographical region, hence, no generalizations beyond the discrete group of nonprofit entrepreneurs examined for this study can be made. Also, in addition to the methodological limitations discussed earlier, it is important to remember the usual caveats regarding a small sample study and its consequent limitations. Still, this author believes the observable differences between necessity nonprofit entrepreneurs and non-necessity entrepreneurs, at a minimum, warrant more research. To initiate and progress the conversation about necessity nonprofit entrepreneurship, the second half of this article will focus on what policy questions arise from the observations reported in this article. This discussion is not meant to convey a normative policy stance, but rather to highlight various policy possibilities for future discussion.

\subsection{Developing Nonprofit Entrepreneurship Metrics}

Nonprofit policymakers and/or funders are better equipped to design and evaluate policies when the measurement techniques at their disposal offer nuance and specificity. Hence, a vital first step is to figure out just how many necessity nonprofit entrepreneurs there are, and where in the nonprofit sector they reside. If necessity entrepreneurship is found to be a fringe phenomenon, it will likely not get (nor will it need) much attention at a policy level. If, however, necessity nonprofit entrepreneurship turns out to be a more prolific phenomenon then it may have implications for the design, funding, and success of nonprofit entrepreneurship policies. Theoretically, one could suspect necessity nonprofit entrepreneurship to be quite common. Cowling and Bygrave (2003) predict the rate of necessity based entrepreneurial activity increases when the barriers to entry into a particular field or market is low and unemployment is high. With regard to entry barriers, Frumkin $(2002,130)$ observed over a decade ago that "[o]ne of the principal reasons the nonprofit and voluntary sector is becoming an attractive vehicle for entrepreneurship is that the barriers to entry is low." With regard to unemployment, the United States witnesses a massive loss of jobs, as during the last recession starting in 2007, and the employment decline during the recession was greater than that of any recession in recent decades (The Bureau of Labor Statistics [BLS] 2012). The combination of low barriers to entry and the effects of the recession point to necessity nonprofits potentially making up a sizeable fraction of new nonprofits being created over the past decade.

Secondly, we also need to gain a better understanding of the outcomes and impact of nonprofit entrepreneurial activity. This is because policymakers and funders may want to target specific types of nonprofit entrepreneurship that yield particular gains. When estimating such gains, such as social innovation or job creation, knowing the overall volume of new nonprofits and the motivations underlying nonprofit entrepreneurship are not sufficient, as neither captures the actual consequences of the entrepreneurial activity.

However, measuring nonprofit entrepreneurship is no easy task. For example, in the past, nonprofit scholars have used the IRS tax exemption rule date as an indicator of when a new nonprofit is created (e. g., Cordes, Steuerle, and Twombly 2004). Yet, empirical evidence indicates nonprofits can be operational for years before obtaining tax exemption (Van Slyke and Lecy 2012). An alternative would be to measure newly incorporated nonprofits. Although this approach still fails to capture informal nonprofit ventures, as well as congregations not electing to incorporate, the incorporation process at the state level precedes applying for federal tax exemption. The incorporation of a new venture thus represents one of the earliest opportunities to tap nonprofit entrepreneurs and create a reference point for future inquiry as the new nonprofit evolves. But incorporation is a state level act, meaning scholars and policy makers would need to collect and aggregate data from all states in order to gauge nonprofit entrepreneurship in the US.

A subsequent challenge is how to differentiate necessity- from non-necessity nonprofit entrepreneurship in the data. One possible option would be to insert questions regarding the nonprofit entrepreneur's current 
employment status and/or specific start-up motivation items when the nonprofit entrepreneur seeks incorporation or federal tax-exemption status. However, targeting the time of incorporation would mean convincing each state to include such measures into the incorporation process, a tall challenge indeed for any researcher or policy maker. Targeting the federal tax exemption process would be beneficial from the standpoint that the data would be collected and stored by the IRS. However, persuading the IRS to include more metrics appears an equally tall challenge given the IRS's recent steps to compress and speed up the federal tax exemption process.

Another option would be to develop a nonprofit equivalent of the Panel Study of Entrepreneurial Dynamics (PSED). The PSED is a collaborative project aimed at identifying a statistically representative sample of on-going venture start-up efforts and subsequently follow these start-up efforts over time to gain insights into entrepreneurial process issues and determinants of outcomes. The PSED includes multiple items regarding start-up motivation, preferences and intentions, which has been the basis for studies of business start-up motivation and careers choice (Cassar 2004). A major hurdle for creating a similar program for the nonprofit sector is cost related. The PSED research program has been tremendously expensive to implement. Based on what we know about the program so far, a PSED for the nonprofit sector would require multiple research collaborators (e. g., universities and research centers), as well as also institutional partners (e. g., The Center for Charitable Statistics) and funders (e. g., foundations or government grants), to finance and design a structure for creating relevant measures, and for collecting, maintaining and administrating on new nonprofits.

\subsection{Offering Assistance or Erecting Barriers}

As indicated in this article, necessity nonprofit entrepreneurs are likely to be different from non-necessity driven entrepreneurs. From a policy perspective, there are multiple considerations emanating from this basic observation, in large part driven by underlying assumptions of the value of nonprofit entrepreneurial activity held by different stakeholders.

From a public policy vantage point, it seems feasible to view all forms of nonprofit entrepreneurship as desirable (e.g., as a powerful mechanism to address social problems, reduce unemployment, empowerment, providing income, and the like). Thus, nonprofit entrepreneurship is regarded as an essential way for individuals to fulfill their needs and pursue their visions and dreams as citizens. It extends the opportunity of self-employment for everyone and allows for broad participation in civil society and the economy, something of particular relevance to unemployed and/or marginalized individuals seeking to reintegrate into local communities. If public policymakers enter from such a vantage point, then creating means for supporting necessity nonprofit entrepreneurs will be needed and worthwhile. Such assistance can come in different forms. For example, the necessity nonprofit entrepreneurs examined in this article were shown to be less experienced and unemployed, suggesting additional training/educational programs could be a way to increase the viability of necessity nonprofit entrepreneurship efforts. Local government and/or federal grants could be made available to organizations to create capacity building programs aimed at supporting unemployed individuals to start new nonprofits at no or low cost. While training and capacity programs are no guarantee for either long- or short-term start-up success, they help build human capital among the unemployed. Furthermore, these types of programs can incentivize those contemplating self-employment in the nonprofit sector as an option to take the plunge. They can also function as testing grounds for nascent necessity nonprofit entrepreneurs to experiment and receive feedback on their start-up effort, which likely will improve the persistence of such efforts?

An alternative is to make funding more easily available for nonprofit entrepreneurial efforts. Given the necessity nonprofit entrepreneurship group displayed a preference to operate small and lean organizations, combined with the general difficulty of securing start-up funding, expanding on The Small Business Administration (SBA) Microloan Program to target new nonprofit ventures could help stimulate and support necessity nonprofit entrepreneurs.

It may also be worthwhile to elevate various forms of "incubators" that offer more direct support to necessity nonprofit entrepreneurs. One example of such an incubator is fiscal sponsorships where eager nonprofit entrepreneurs can launch and test new ideas without having to obtain tax-exempt status or build a full-fledged organization as the fiscal sponsor helps provide administrative and/or managerial services and assumes some or all of the legal and financial responsibility for the activities of the nonprofit entrepreneur (Colvin 2006). However, according to Blair and Cheplick (2007), fiscal sponsorship remains an underutilized and often misinterpreted resource in need of better clarification and promotion. Efforts to boost the use of fiscal sponsors as a less resource intensive, and in-between option to create a full-fledged new nonprofit, seems particularly appropriate for necessity based nonprofit entrepreneurs given their relative lack of start-up know-how and propensity to consider the new venture as a stopgap activity.

A very different vantage point to nonprofit entrepreneurship can often be found among a different group of stakeholders, predominantly residing in the philanthropic/nonprofit funding community. As commented 
by Shoemaker (2011), "[i]f you ask just about any philanthropist, [...] they'll tell you there are 'too many nonprofits.' They need to merge or consolidate. Or at the extreme, more of them need to 'go out of business.'” Instead of associating nonprofit entrepreneurship with increased dynamism and new value creation, the consistent influx of new nonprofit organizations is perceived as leading to overcrowding and draining of resources (McCambridge and Johnson 2016). Consequently, encouraging nonprofit entrepreneurship will only dilute an already scarce resource base, undermining the effectiveness of individual organizations and ultimately the sector at large (Callahan 2015; Pfeiffer 2016). From this vantage point, necessity nonprofit entrepreneurship becomes an unlikely target for philanthropic funding. Given the fragility, short-term orientation, and limited impact expected of necessity nonprofit entrepreneurs, the opportunity cost for supporting this group is likely greater compared to targeting non-necessity entrepreneurs or already established nonprofits. Consequently, funders will elect to allocate their scarce resources to nonprofits with the greater chance of survival and longterm impact.

An even more assertive policy option would be to erect barriers to entry for nonprofit entrepreneurship, on the basis that policy makers only want to encourage serious and determined entrepreneurial efforts. One such entry barrier is to compel the nonprofit entrepreneur to personally invest in the new nonprofit. Such a policy would impact necessity nonprofit entrepreneurs in particular, given they are less likely to have startup resources at hand (Block et al. 2015). An example of this type of entry barrier is highlighted by Andersson and Ford (2017) who examined founding rates of new nonprofit voucher schools in Milwaukee. In response to concerns over the quality of new nonprofit voucher schools, the Wisconsin legislators passed legislation creating a $\$ 1,300$ application fee for any nonprofit entrepreneur wanting to open a new school. The new fee, in combination with establishment of a new school approval board, had a striking depressing effect on the creation of new nonprofit voucher school ventures. As illustrated by Andersson and Ford $(2017,78)$ the number of nonprofit entrepreneurs attempting to open a new voucher school the year before the legislation passed was 53 , and in the year after the legislation the number was 6. Obviously, this study only looked at one geographical area, and focused on a specific type of nonprofit. Still, the above example illuminates how policy and policy decisions can have a chilling effect on new nonprofit entry.

To summarize, policies are powerful tools for eliciting and/or do away with barriers to entry, thereby having a direct impact on the supply of nonprofit entrepreneurs (Harrison and Thornton 2014). As this article illuminates, necessity nonprofit entrepreneurship has distinct features and this distinctiveness is something policy makers ought to consider when crafting nonprofit entrepreneurship policy. For example, creating pecuniary entry barriers is likely to have a much more significant impact on the rate of necessity-based nonprofit entrepreneurs. Still, robust data for analyzing nonprofit entrepreneurship (e. g., entrepreneur demographics, nascent activity, success- and failure rates) remains scarce, and as a consequence we know very little about the marginal effects of spending resources supporting necessity and non-necessity nonprofit entrepreneurship.

\section{Conclusion}

New nonprofits are created by people, meaning nonprofit entrepreneurship is closely related to the decisions that individuals make about why and how to undertake the organizational creation process. Thus, human motivation plays a notable role in understanding the nonprofit entrepreneurial process. To date, nonprofit entrepreneurs have predominantly been portrayed as intrinsically motivated and altruistic. This article has illustrated how individuals are sometimes pushed, acting out of necessity, into creating new nonprofits, and argued that this perspective remains overlooked and under researched in current nonprofit scholarship.

Although the empirical findings presented in this study are preliminary and limited, the results indicate there are differences between necessity and other types of nonprofit entrepreneurs that are important to comprehend. A principal conclusion to be drawn from this article is that policymakers and other stakeholders need more and better data on nonprofit entrepreneurship. For example, to better grasp what is incentivizing/disincentivizing nonprofit entrepreneurs, we need good data on why individuals elect to start new nonprofits. Mapping why and how new nonprofits are created is also going to be a vital element in establishing how to best craft nonprofit entrepreneurship policies.

\section{References}

Acs, Z. 2006. "How Is Entrepreneurship Good for Economic Growth?." Innovations 1 (1): 97-107.

Andersson, F. O. 2016. "Nascent Nonprofit Entrepreneurship: Exploring the Formative Stage of Emerging Nonprofit Organizations." Nonprofit and Voluntary Sector Quarterly 45 (4): 806-824. 
Andersson, F. O., and M. Ford. 2017. “Entry Barriers and Nonprofit Founding Rates: An Examination of the Milwaukee Voucher School Population." Nonprofit Policy Forum 8 (1): 71-90.

Bess, C. 1998. "A First Stage Organization Life Cycle Study of Six Emerging Nonprofit Organizations in Los Angeles." Administration in Social Work 22 (4): 35-52.

Blair, J., and T. Cheplick. 2007. More than the Money: Fiscal Sponsorship's Unrealized Potential. Berkeley, CA: BTW's Informing Change Series.

Block, J. H., K Kohn, D. Miller, and K. Ullrich. 2015. “Necessity Entrepreneurship and Competitive Strategy.” Small Business Economics 44 (1): $37-54$.

Boluk, K. A., and Z. Mottiar. 2014. "Motivations of Social Entrepreneurs." Social Enterprise Journal 10 (1): 53-68.

Bornstein, D. 2004. How to Change the World: Social Entrepreneurs and the Power of New Ideas. Oxford, UK: Oxford University Press.

Brewer, ]. 2014. "Defining and Classifying Necessity Entrepreneurs: A Review of the Literature." In Necessity Entrepreneurs. Microenterprise Education and Economic Development, edited by ]. Brewer and S. Cibson, 1-22. Cheltenham UK: Edward Elgar.

The Bureau of Labor Statistics [BLS]. 2012. The Recession of 2007-2009. BLS Spotlight on Statistics. Available at. http://www.bls.gov/spotlight/2012/recession/pdf/recession_bls_spotlight.pdf.

Callahan, D. 2015. There are Way Too Many Nonprofits. What are Funders Coing to Do about That? Inside Philanthropy, January 14. Available at. https://www.insidephilanthropy.com/home/2015/1/14/there-are-way-too-many-nonprofits-what-are-funders-going-to.html.

Carman, J. G., and R. Nesbit. 2013. “Founding New Nonprofit Organizations: Syndrome or Symptom?.” Nonprofit and Voluntary Sector Quarterly 42 (3): 603-621.

Cassar, G. 2004. “Entrepreneur Motivation, Growth Intentions and Preferences.” Frontiers of Entrepreneurship Research 19: 422-435.

Chambré, S. M., and N. Fatt. 2002. "Beyond the Liability of Newness: Nonprofit Organizations in an Emerging Policy Domain." Nonprofit and Voluntary Sector Quarterly 31 (4): 502-524.

Child, C., E. M. Witesman, and D. B. Braudt. 2015. "Sector Choice How Fair Trade Entrepreneurs Choose between Nonprofit and For-Profit Forms." Nonprofit and Voluntary Sector Quarterly 44 (4): 832-851.

Christopoulos, D., and S. Vogl. 2015. "The Motivation of Social Entrepreneurs: The Roles, Agendas and Relations of Altruistic Economic Actors." Journal of Social Entrepreneurship 6 (1): 1-30.

Colvin, G. L. 2006. Fiscal Sponsorship: Six Ways to Do It Right, 2nd ed. San Francisco, CA: Study Center Press.

Cordes, J. J., C. E. Steuerle, and E. Twombly. 2004. “Dimensions of Nonprofit Entrepreneurship: An Exploratory Essay." In Public Policy and the Economics of Entrepreneurship, edited by D. Holtz-Eakin and H. S. Rosen, 115-151. Cambridge, MA: MIT Press.

Cowling, M., and W. D. Bygrave. 2003. Entrepreneurship and Unemployment: Relationships between Unemployment and Entrepreneurship in 37 Nations Participating in the Clobal Entrepreneurship Monitor (CEM) 2002. Frontiers of Entrepreneurship Research. Boston, MA: Babson.

Dollhopf, E. J., and C. P. Scheitle. 2016. “Explaining Variations in the Nonprofit Founding Process." Nonprofit Management and Leadership 27 (2): 261-272.

Frumkin, P. 2002. On Being Nonprofit: A Conceptual and Policy Primer. Boston: Harvard University Press.

Gartner, W. B. 1988. ““Who Is an Entrepreneur?” Is the Wrong Question.” American Journal of Small Business 12 (4): 11-32.

Germak, A. J., and J. A. Robinson. 2014. “Exploring the Motivation of Nascent Social Entrepreneurs." Journal of Social Entrepreneurship 5 (1): 5-21.

Gibson, S. 2014. "Understanding and Helping the Necessity Entrepreneur Prosper." In Necessity Entrepreneurs. Microenterprise Education and Economic Development, edited by ]. Brewer and S. Cibson, 23-39. Cheltenham UK: Edward Elgar.

Handy, F., M. Kassam, and S. Renade. 2002. "Factors Influencing Women Entrepreneurs of NCOs in India." Nonprofit Management and Leader$\operatorname{ship} 13$ (2): 139-154.

Harding, R. 2004. “Social Enterprise: The New Economic Engine?.” Business Strategy Review 15 (4): 39-43.

Harrison, T., and ]. Thornton. 2014. "Too Many Nonprofits? an Empirical Approach to Estimating Trends in Nonprofit Demand Density." Nonprofit Policy Forum 5 (2): 213-229.

Hasenfeld, Y., and H. Schmid. 1989. "The Life Cycle of Human Service Organizations: An Administrative Perspective." Administration in Social Work $13(3 / 4): 243-269$

Haugh, H. 2005. “A Research Agenda for Social Entrepreneurship." Social Enterprise Journal 1 (1): 1-12.

Hjorth, D., and B. Johannisson. 2008. "Building New Roads for Entrepreneurship Research to Travel By: On the Work of William B. Gartner." Small Business Economics 31 (4): 341.

McCambridge, R., and K. Johnson. 2016. Too Many Nonprofits? Or Too Many Silly Questions. Nonprofit Quarterly Online, July 26. Available at. https://nonprofitquarterly.org/2016/07/26/many-nonprofits-many-silly-questions/.

McKeever, B. 2015. The Nonprofit Sector in Brief 2015: Public Charities, Giving, and Volunteering. Washington DC: Urban Institute.

Pfeiffer, S. 2016. Dose Boston Have Too Many Nonprofits? Boston Clobe, July 4. Available at.

http://www.bostonglobe.com/business/2016/07/04/does-boston-have-too-many-nonprofits-some-sayyes/XMnV259wjXdugZqrOl3Cvl/story.html.

Poschke, M. 2013. “Entrepreneurs Out of Necessity: A Snapshot.” Applied Economics Letters 20 (7): 658-663.

Reynolds, P., W. D. Bygrave, E. Autio, L. W. Cox, and M. Hay. 2003. Clobal Entrepreneurship Monitor 2002 Executive Report. Wellesley, MA: Babson College.

Santos, F. M. 2012. “A Positive Theory of Social Entrepreneurship." Journal of Business Ethics 111 (3): 335-351.

Sastre-Castillo, M. A., M. Peris-Ortiz, and D. D. Valle. 2015. "What Is Different about the Profile of the Social Entrepreneur?." Nonprofit Management and Leadership 25 (4): 349-369.

Segal, G., D. Borgia, and ]. Schoenfeld. 2005. "The Motivation to Become an Entrepreneur." International Journal of Entrepreneurial Behavior 8 Research 11 (1): 42-57.

Shane, S., E. A. Locke, and C. J. Collins. 2003. "Entrepreneurial Motivation." Human Resource Management Review 13 (2): 257-279.

Shane, S., and S. Venkataraman. 2000. "The Promise of Entrepreneurship as a Field of Research." Academy of Management Review 25 (1): $217-$ 226. 
Shoemaker, P. 2011. Too Many NonProfits? It's Time for Funders to Consolidate. Huffington Post, October 20. Available at. https://www.huffingtonpost.com/paul-shoemaker/too-many-nonprofits-its-t_b_1020721.html.

Simon, J. S. 2001. The Five Life Stages of Nonprofit Organizations. Where You Are, Where You're Coing, and What to Expect When You Cet There. Saint Paul, MN: Amherst H. Wilder Foundation.

Stevens, S. K. 2001. Nonprofit Lifecycles: Stage-Based Wisdom for Nonprofit Capacity. Long Lake, MN: Stagewise Enterprises.

Van Slyke, D. M., and J. Lecy. 2012. “Profiles of Nonprofit Startups and Nonprofit Entrepreneurs." Paper presented at the ARNOVA National Conference, Indianapolis, November 15-17.

Young, D. R. 1983. If Not for Profit, for What?. Lexington: D. C. Heath and Company.

Zahra, S. A., E. Cedajlovic, D. O. Neubaum, and J. M. Shulman. 2009. “A Typology of Social Entrepreneurs: Motives, Search Processes and Ethical Challenges." Journal of Business Venturing 24 (5): 519-532. 